\title{
ANALÝZA PARAMETROV INJEKČNEJ CLONY V PODLOŽÍ PRIEHRADY VLČIA DOLINA
}

\author{
ANALYSIS OF PARAMETERS OF THE INJECTION CURTAIN IN THE \\ BEDROCK OF THE VLČIA DOLINA DAM
}

\author{
Patrik Václavik ${ }^{*}, 1$ \\ "patrik.vaclavik@stuba.sk \\ Slovenská technická univerzita v Bratislave, Stavebná fakulta, Katedra geotechniky, Radlinského 11, 81005 Bratislava, Slovenská \\ republika ${ }^{2}$
}

\begin{abstract}
Abstrakt
Ciel'om predkladaného článku je analýza parametrov injekčnej clony (IC) v podloží vodného diela Vlčia Dolina s prihliadnutím na modernejšie kritéria pre vodné tlakové skúšky (VTS). Vstupné údaje pre hodnotenie injekčnej clony boli prevzaté z výsledkov vodných tlakových skúšok. Pri návrhu parametrov injekčnej clony v dobe jej výstavby boli používané Lugeonové, príp. Jädeho kritéria. V súčasnej dobe, takmer 70 rokov od započatia prevádzky vodného diela sa pre návrh parametrov (híbka) používajú novšie kritéria, ako napr. Verflove alebo Houlsbyho. Účelom predkladaného článku je najmä analýza vhodnosti použitia spomínaných kritérií (Jähde, Verfel, Houlsby) v podmienkach podložia priehrady Vlčia Dolina. Metódou konečných prvkov (MKP) bola hl'adaná optimálna hĺbka injekčnej clony.
\end{abstract}

\section{Kl'účové slová}

Priehrada, podložie, vodné tlakové skúšky, piezometrická výška, vztlak

\begin{abstract}
Goal of this article is to analyze the parameters of the curtain grouting (CG) in the bedrock of the Vlčia Dolina dam, using the modern criteria for water pressure tests (WPT). The input data for the evaluation of the CG were taken from the results of the water pressure tests. When designing the parameters of the injection screen at the time of its construction, Lugeons criteria were used. At present, 70 years after the start of operation of the waterworks, newer criteria are used for the design of parameters (depth). The purpose of the presented article is mainly the analysis of the suitability of the use of the criteria (Jähde, Verfel, Houlsby) in the conditions of the bedrock of the Vlčia Dolina dam. The finite element method (FEM) was used to find optimal depth of the curtain grouting.
\end{abstract}

\section{Key words}

Dam, bedrock, water pressure test, piezometric height, uplift pressure

\section{1 ÚVOD}

Bezpečnost' vodných stavieb, ako sú priehrady, ochranné hrádze, poldre či odkaliská, je vo svete stále aktuálnou témou. Ich úlohou je najmä protipovodňová ochrana, zásobovanie obyvatel'stva pitnou vodou, výroba elektrickej energie, závlahy a d'alšie. Aby mohli tieto úlohy spol'ahlivo plnit', je nevyhnutné venovat' pozornost' funkcii protipriesakových opatrení, ktorá je bezprostredne spojená s bezpečnost’ou hrádzí vodných stavieb. Ich optimálny návrh je determinovaný spol'ahlivost’ou inžiniersko-geologických podkladov. Osobitý význam v procese riešenia filtračných úloh má priepustnost' horninového prostredia Pri určovaní priepustnosti skalných hornín zastávajú popredné miesto vodné tlakové skúšky (VTS) . V prípade nepriaznivých výsledkov vodných tlakových skúšok sa pristupuje k nákladnému utesňovaniu podložia priehrad, najčastejšie pomocou injekčných clôn. 


\section{STRUČNÁ CHARAKTERISTIKA VODNÉHO DIELA}

Vodná nádrž Vlčia Dolina bola vytvorená prehradením údolia Vlčej doliny betónovou gravitačnou priehradou [1]. Výška telesa priehrady nad terénom je 19 m, nad základovou škárou 27 m (Obr. 1). Koruna priehrady sa nachádza na kóte $512,60 \mathrm{~m} \mathrm{n}$. m. Dížka priehrady v korune je $137,60 \mathrm{~m}$. Teleso priehrady je vytvorené 15 -timi blokmi dížky 6 až $12 \mathrm{~m}$. Návodné líce je v sklone $1: 0,03$, vzdušné v sklone $1: 0,72$. V oblasti základovej škáry majú bloky šírku 6 až $17 \mathrm{~m}$, híbka založenia blokov pod terénom sa nachádza v rozmedzí 4 až $7 \mathrm{~m}$. Bezpečnostný priepad pozostáva zo štyroch polí šírky 3,30 m, ktoré sa nachádzajú na blokoch v l’avostrannej oblasti údolnej nivy.

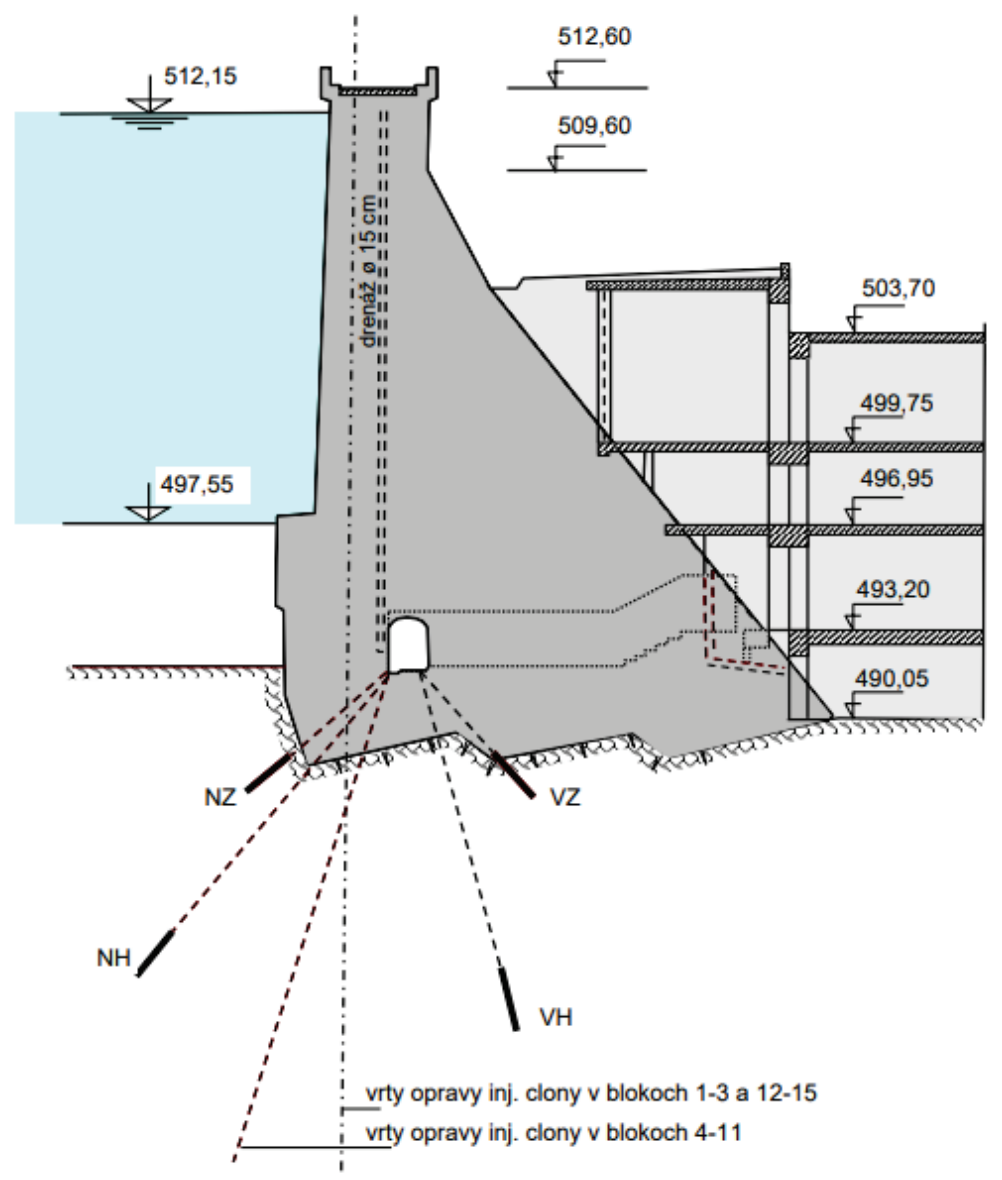

Obr. 1 Schéma priečneho profilu priehrady Vlčia Dolina [1].

\section{Popis geologickej skladby podložia}

Záujmové územie predstavuje komplex vulkanických a sedimentačných hornín, pričom prevahu majú vulkanické horniny (Obr. 2). Skalný podklad priehrady tvoria v prevažnej miere amfibolity zelenej, sivozelenej až čiernej farby, s množstvom kremeňa rôznej mocnosti a s tenkými žilkami sideritu, ankeritu, magnezitu a živcov. Pokryvné vrstvy mocnosti maximálne $4 \mathrm{~m}$ sa skladajú zo sutových hlín, štrkov a kamenitých sutí. Výstavba priehrady v hlbokom údolí Vlčej bola sprevádzaná problémami. Za zmienku stojí napr. zosun asi $25000 \mathrm{~m}^{3}$ horniny, ktorý vznikol pri zakladaní priehrady v pravom údolnom svahu. 


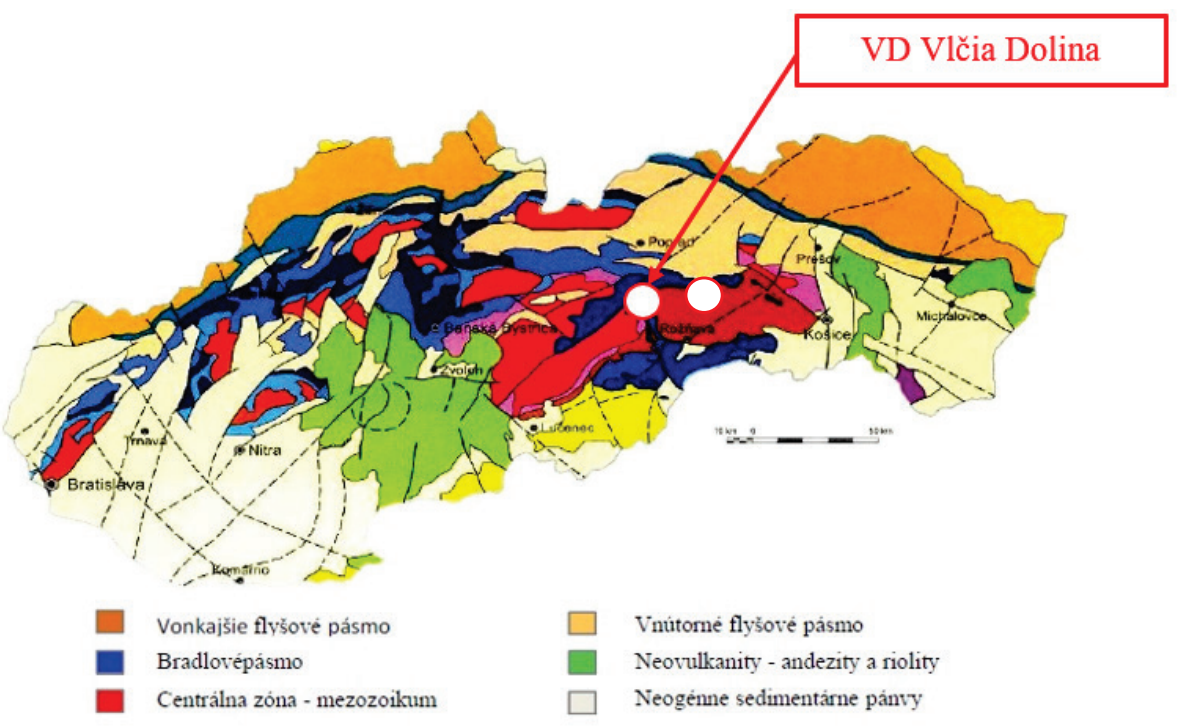

Obr. 2 Geologická mapa Slovenska s vyznačením polohy priehrady Vlčia Dolina [2].

\section{VODNÉ TLAKOVÉ SKÚŠKY}

Vodnými tlakovými skúškami stanovujeme priepustnost’ hornín. Vodné tlakové skúšky sú stále najkomplexnejšie a najvyužívanejšie metódy na určenie priepustnosti skalných hornín. Podstata skúšky spočíva vo vháňaní vody do uzatvoreného priestoru vrtu (skúšanej etáže) pod tlakom a sledovanie množstva straty vody v posudzovanej etáži v $1 . \min ^{-1} \cdot \mathrm{m}^{-1}$, z čoho sa následne stanoví priepustnost' horniny. Základná jednotka, v ktorej hodnotu priepustnosti uvádzame, koeficient filtrácie, je v m. $\mathrm{s}^{-1}$. Okrem stanovenia spotreby vody v jednotlivých híbkových úrovniach možno orientačne určit’ aj charakter puklinového prostredia testovaného masívu - výplň a jej stabilitu, hodnotu tlaku, pri ktorom ešte nedochádza k deformáciám skalného podložia a pod. Pre umožnenie splnenia týchto podmienok je nutné priebeh vodných tlakových skúšok usporiadat' tak, aby boli dosiahnuté výsledky spol'ahlivé a nedochádzalo k obtekaniu obturátora a aby bola známa hodnota tlaku pri ktorom bola skúška realizovaná [3].

\section{Kritéria pre vodné tlakové skúšky}

Princíp vodných tlakových skúšok nespočíva iba v určení hydraulickej vodivosti, resp. koeficientu filtrácie skalného podložia, no i na zhodnotení a posúdení potreby utesnenia podložia pod stavebnými objektami ako sú napr. priehrady, prípadne iné vodné stavby. Na určenie takýchto parametrov podložia boli stanovené kritéria podl'a rôznych autorov [Tab. 1], [Tab. 2]. Ich vývoj bol v časovom i priestorovom horizonte rozmanitý a nachádzali uplatnenie v rôznych podmienkach, či už hydrologických, geologických alebo geografických.

Kritérium pre vodnú tlakovú skúšku chápeme ako hodnotu straty vody, po prekročení ktorej je nutné pristúpit' $\mathrm{k}$ utesneniu podložia priehrady.

Tab. 1 Kritéria dovolených strát vody pri VTS - pre priehrady s výškou nad $30 \mathrm{~m}$.

\begin{tabular}{cc}
\hline Autor & Kritérium prípustných strát vody pri VTS \\
\hline Lugeon & $1 \mathrm{LU}$ resp. $0,31 \mathrm{~min}-1 . \mathrm{m}-1 \mathrm{pri} 0,3 \mathrm{MPa}$ \\
Jähde & $0,1-0,5 \mathrm{l} / \mathrm{min} / \mathrm{bm}$ pri $0,3 \mathrm{MPa}$ \\
Terzaghi & $0,05 \mathrm{l} / \mathrm{min} / \mathrm{m}$ pri $10 \mathrm{kPa}$ \\
Heitfeld & $2,5-4 \mathrm{LU}$ \\
USSR & $3 \mathrm{LU}$ \\
USA & $3-4 \mathrm{LU}$ \\
\hline
\end{tabular}


Pri určení prípustných strát vody pri VTS použil odlišný prístup Verfel [3]. Jeho metóda vychádzala z poznania, že priesaková dráha prúdiacej vody sa s narastajúcou híbkou predlžuje, čoho dôsledkom sú nižšie hodnoty gradientov vo väčších híbkach a teda aj menšie hydrodynamické namáhanie horninového prostredia. Obvykle sa s narastajúcou híbkou znižuje i rozpukanost' skalného masívu. Vzhl'adom na tieto úvahy stanovil kritéria, zohl'adňujúc hĺbku, v ktorej VTS realizuje [Tab. 2].

Tab. 2 Kritéria dovolených strát vody pri VTS podl'a Verfla.

\begin{tabular}{ccc}
\hline $\begin{array}{c}\text { Qdov } \\
\text { (l. min-1. m-1) }\end{array}$ & $\begin{array}{c}\text { Skúšobný tlak } \\
\text { (MPa) }\end{array}$ & $\begin{array}{c}\text { Híbka pod základovou škárou } \\
(\mathbf{m})\end{array}$ \\
\hline 0,5 & 0,3 & $0-10$ \\
1,5 & 0,3 & $10-20$ \\
2,5 & 0,3 & $20-30$ \\
4,0 & 0,3 & $30-50$ \\
6,0 & 0,3 & $>50$ \\
\hline
\end{tabular}

\section{Analýza výsledkov vodných tlakových skúšok}

Úlohou analýzy výsledkov VTS bolo najmä porovnat' namerané straty vody s hodnotiacimi kritériami podl’a Jähdeho, Houlsbyho a Verfla. Prezentované hodnoty strát pri VTS v podmienkach priehrady Vlčia Dolina boli prevzaté z dokumentácie, ktorá bola spracovaná pri rekonštrukcii injekčnej clony v roku 1978 [4], [5]. Grafická analýza výsledkov bola spracovaná pre podložie všetkých blokov telesa priehrady. Pre ilustráciu dokumentujem na Obr. 3 dokumentované výsledky, prislúchajúce podložiu pod blokom priehrady č.6. Vodorovná os zodpovedá stratám vody pri VTS (1/ min/ bm pri tlaku $0,30 \mathrm{MPa})$, vertikálna os prezentuje híbku skúšanej etáže pod základovou škárou. Súvislými čiarami sú vynesené kritéria podl’a Jähdeho (zelenou farbou), Houlsbyho (žltou farbou) a Verfla (červenou farbou). Prerušovanými čiarami sú vykreslené výsledky strát vody vo vrtoch I-6-1 a I-6-5, v ktorých boli realizované VTS pod daným blokom.

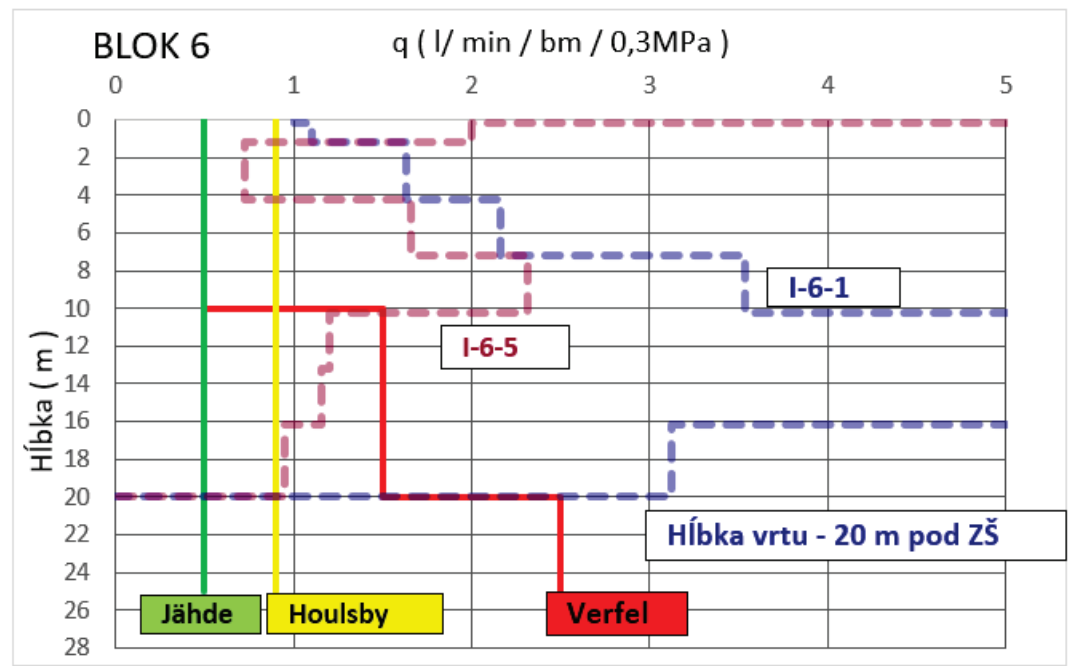

Obr. 3 Porovnanie strát vody pri VTS s kritériami podl’a Verfla, Houlsbyho a Jähdeho v podloží bloku 6 [6].

\section{POSÚDENIE VHODNOSTI KRITÉRIÍ PRE VTS METÓDOU KONEČNÝCH PRVKOV}

Pre posúdenie optimálnej híbkyinjekčnej clony v podloží priehrady Vlčia Dolina a súčasne aj pre overenie vhodnosti kritérií pre VTS bola zvolená metóda konečných prvkov (MKP). Vol'ba metódy vyplynula z charakteru úlohy, ktorý vyžaduje podrobnú analýzu parametrov filtračného prúdenia v oblasti injekčnej clony. V teoretickej 
rovine sa jedná o rovinný problém. Riešenie bolo uskutočnené vo vertikálnej rovine. Matematické riešenie úloh ustáleného filtračného prúdenia v rovine vyplýva z rovnice (1) odvodenej z rovnice kontinuity a Darcyho filtračného zákona [7]:

$$
\frac{\partial}{\partial x}\left(k_{x} \frac{\partial h}{\partial x}\right)+\frac{\partial}{\partial y}\left(k_{y} \frac{\partial h}{\partial y}\right)=-q,
$$

kde h je piezometrická výška (m), kx, ky súčinitel’ filtrácie v smere osí x, y (m. s-1), q - prítok respektíve odtok vody z riešenej oblasti (m. s-1).

K analýze zadanej úlohy bol využitý software Geostudio, modul Seep/ W, nakol'ko umožňuje riešenie úloh filtračného prúdenia MKP v horizontálnej i vertikálnej rovine s tlakovou i vol'nou hladinou. Pri riešení filtračného pohybu podložím betónovej priehrady boli použité Dirichletova a Neumanova okrajová podmienka . Koeficient filtrácie podložia priehrady, ako najdôležitejší faktor pre návrh injekčnej clony, bol stanovený z výsledkov VTS podl'a viacerých autorov a to: Dupuit, Verigin, Moye a Hoek - Bray [9]. Hodnoty uvažované vo výpočtoch sú zakomponované do Obr. 4.

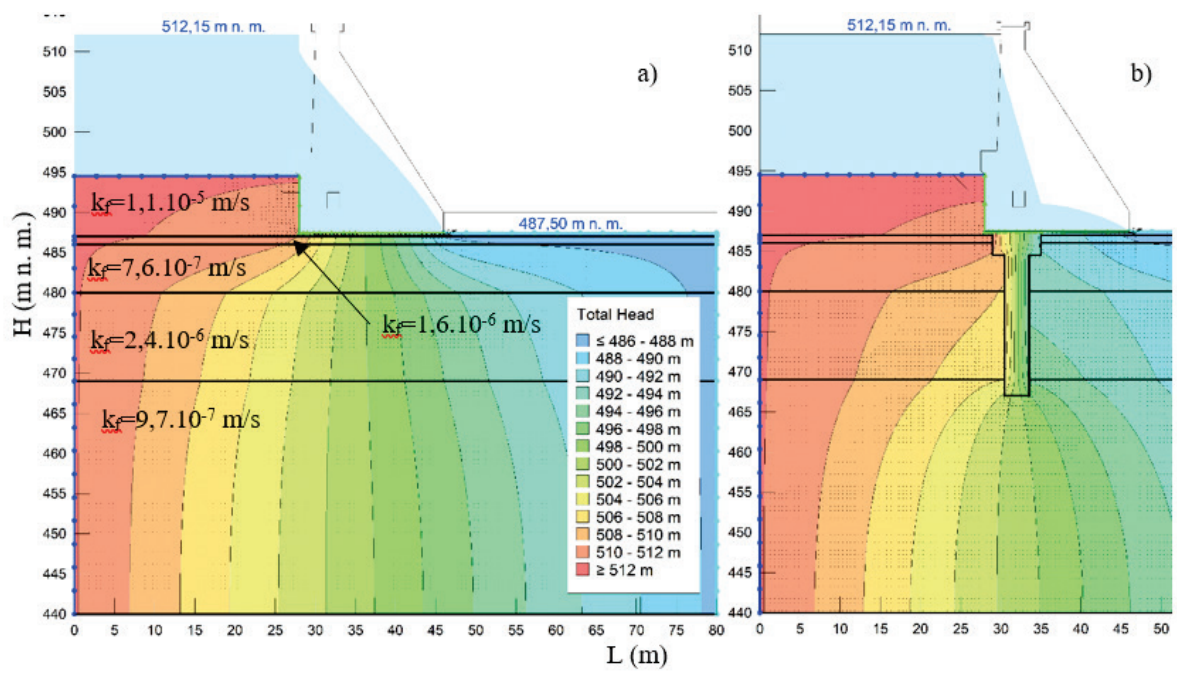

Obr. 4 Vývoj piezometrických výšok a) bez injekčnej clony b) pri híbke IC 20 m, s fortifikačnou injektážou do híbky $3 \mathrm{~m}[6]$.

Výstupy získané na základe numerických výpočtov MKP sú graficky zobrazené na Obr. 5. Hodnoty piezometrických výšok sú odčítané z oblasti tesne za injekčnou clonou v blízkosti základovej škáry. Z výsledkov je zrejmé, že redukcia injekčnej clony sa najvýraznejšie prejavuje do híbky približne $20 \mathrm{~m}$. Prehlbovanie IC nad túto hodnotu neprináša d̋̌iu redukciu vztlakov, tento výsledok potvrdzuje Verflove kritérium.

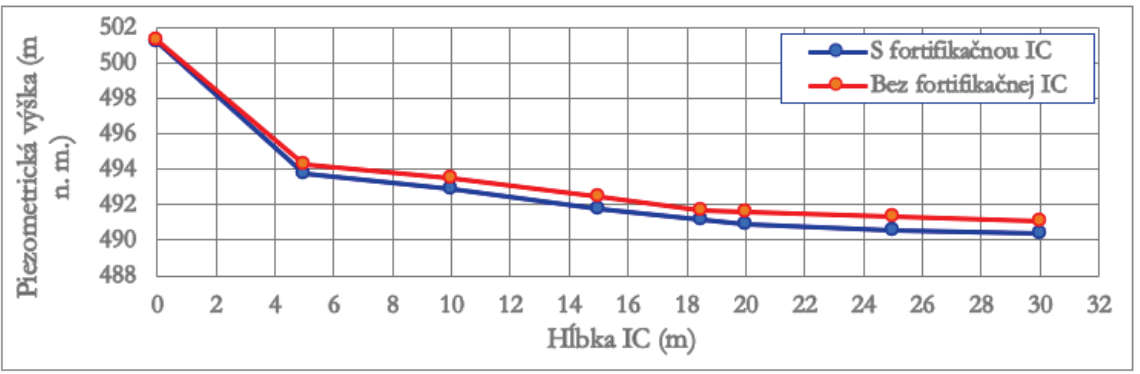

Obr. 5 Vývoj piezometrických výšok v závislosti od hĺbky IC - blok 6 . 


\section{ZÁVER}

Z dosiahnutých výsledkov, na ilustrovanom príklade posúdenia injekčnej clony v podloží bloku v údolnej nive priehrady Vlčia Dolina vyplýva, že optimálna híbka injekčnej clony najviac konvertovala ku kritériám podl’a Verfla. Získané výsledky potvrdzujú, že kritéria odstupňované s híbkou pod základovou škárou sú opodstatnené a najlepšie vystihujú potrebu utesnenia podložia priehrady. Súčasne treba poznamenat', že možnosti numerického modelovania MKP predstavujú významné miesto v hladaní optimálnych parametrov protipriesakových opatrení v súbore vodných stavieb. Ich spol’ahlivost' je však determinovaná spol’ahlivost'ou vstupných údajov - poznania geologickej skladby podložia.

Pozoruhodné je aj poznanie, že skutočné parametre IC v podloží priehrady Vlčia dolina sú vo vel'mi dobrej zhode s novšími kritériami, konkrétne s kritériami podl’a Verfla. Tento fakt súčasne potvrdzuje mimoriadne schopnosti, poznatky a skúsenosti vodohospodárov, priehradárov, geológov a d'., ktorí stáli pri zrode takých vodných diel, akým je priehrada Vlčia Dolina [Obr. 6] ale aj Palcmanská Maša, Orava, Nosice a i. Sú to vodné stavby, vybudované v 50-tych až 70-tych rokoch minulého storočia, bez akéhokolvek využitia výpočtovej techniky. V súčasnosti si projektovanie takýchto významných inžinierskych (hydrotechnických) konštrukcií bez dostupných programov a počítačovej techniky nevieme predstavit'.

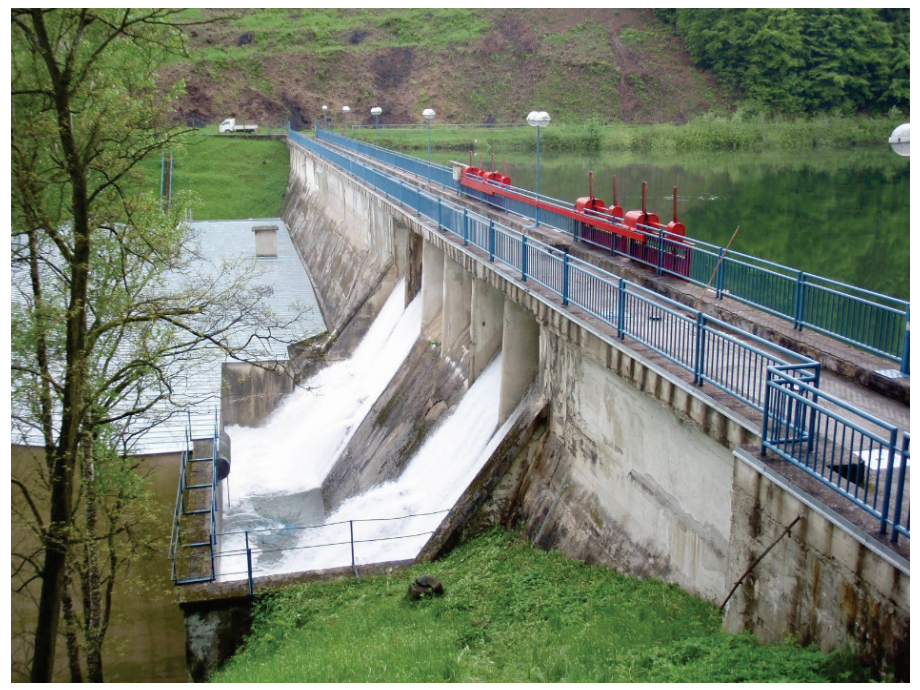

Obr. 6 Vodné dielo Vlčia Dolina [Foto: Uhorščák, L'.].

\section{Použité zdroje}

[1] Bednárová, E. Lukáč, M. Minárik, M. Bakaljarová, M. Lipták, B. Miščík, M. Panenka, P. Stoličný, J. Priehradné stavitel'stvo na Slovensku: Originality. Mil'níky. Zaujímavosti. Bratislava : KUSKUS,s.r.o., 2010. ISBN 978-80-970428-0-6.

[2] Vodné dielo Dobšiná - priehrada Vlčia Dolina hydrogeolog. prieskum. Žilina : IGHP n. p. závod Žilina, 1978.

[3] Minasny, B., Contrasting soil penetration resistance values acquired from dynamic and motor operated penetrometers, 2012, Geoderma vol. 177-178, p. 57-62.

[4] Vodné dielo Dobšiná - priehrada Vlčia Dolina hydrogeolog. prieskum. Žilina : IGHP n. p. závod Žilina, 1978.

[5] VD DOBŠINÁ priehrada vo Vlčej Doline inž. geolog. prieskum. s.l. : IGHP n. p. závod Žilina, 1978.

[6] Václavik, P. Prehodnotenie parametrov injekčnej clony na vodnom diele Vlčia Dolina. Bratislava : Slovenská technická univerzita v Bratislave, 2020.

[7] T. S. Darcy, F. Fuan. Groundwater and the enviroment, The 2nd Annual Enviromental Rngineering Workshop, Groundwater modeling case studies. 1996.

[8] Geostudio 2016 - user manual. Alberta, Canada : GEO-SLOPE International Ltd, 2016.

[9] Lukáč, M. Bednárová, E. . Nádrže a priehrady: Navrhovanie a prevádzka. s.1. : STU v Bratislave, 2001. ISBN 80-227-1518-2. 